\title{
Sosis Ikan Kembung (Rastrelliger Kanagurta L.) Sebagai Pangan Sumber Omega 3
}

\author{
Long Jawed Mackerel Fish Sausages ( Rastrelliger kanagurta L. ) As Food Sources of Omega 3 \\ Iwenda Nalendrya, Ibnu Malkan Bakhrul Ilmi, Firlia Ayu Arini \\ Fakultas IImu-IImu Kesehatan, Jurusan IImu Gizi, Universitas Pembangunan Nasional "Veteran" Jakarta \\ *Korespondensi dengan penulis (niwenda@gmail.com) \\ Artikel ini dikirim pada tanggal 8 April 2016 dan dinyatakan diterima tanggal 10 Juni 2016. Artikel ini juga dipublikasi secara online melalui \\ www.jatp.ift.or.id. Hak cipta dilindungi undang-undang. Dilarang diperbanyak untuk tujuan komersial. \\ Diproduksi oleh Indonesian Food Technologists $® ~ @ 2016$
}

\begin{abstract}
Abstrak
Penggunaan bahan kimia pada jajanan anak di Indonesia semakin meningkat. Data BPOM menunjukan pada tahun 2010 pangan jajanan anak sekolah yang tidak memenuhi syarat sebanyak $35,46 \%$. Penggunan formalin dan boraks pada makanan ringan berturut-turut sebesar $16,06 \%$ dan $9,11 \%$. Perlu dikembangkan pangan sehat bagi anak yang dapat membantu perkembangan otak. Asam lemak esensial omega 3 dibutuhkan dalam pembentukan sel-sel otak untuk meningkatkan tingkat intelegensia. Omega 3 dapat ditemukan di produk perikanan. Namun, tingkat konsumsi ikan di Indonesia masih rendah bila dibandingkan dengan rekomendasi FAO. Ikan kembung (Rastrelliger kanagurta L.) merupakan ikan air laut yang banyak mengandung omega 3 yang baik bagi kecerdasan otak. Penelitian ini bertujuan untuk mengembangkan formulasi sosis dari ikan kembung sebagai pangan sumber omega 3 . Metode yang digunakan adalah eksperimental dengan menggunakan desain rancangan acak lengkap. Penambahan ikan segar yang digunakan sebanyak $30 \mathrm{~g}$ (FS1), $45 \mathrm{~g}$ (FS2), dan $60 \mathrm{~g}$ (FS3), sedangkan tepung ikan yang digunakan 6,75 g (FT1), $13 \mathrm{~g}$ (FT2) dan $20 \mathrm{~g}$ (FT3). Formula terbaik hasil uji organoleptik adalah FS2 yang mengandung $44,48 \%$ air, abu $2,65 \%$, protein $9,4 \%$, lemak $5,48 \%$, karbohidrat $37,88 \%$, energi $238,48 \mathrm{kkal}$ dan omega 3 sebesar $0,18 \mathrm{~g} / 100 \mathrm{~g}$. Kandungan omega 3 sosis ikan kembung per $100 \mathrm{~g}$ dapat menjadi sumber omega 3 dengan menyumbang $20 \%$ kecukupan omega 3 anak.
\end{abstract}

Kata kunci: sosis, ikan kembung, omega 3, cerdas.

\begin{abstract}
The use of chemicals on children's snacks in Indonesia is increasing. Data from BPOM show in 2010 school children's snacks which is not qualified as much as $35,46 \%$. The use of formaline and borax on snacks are $16.06 \%$ and $9.11 \%$. It is necessary to develop healthy food for children which can help brain development. Omega 3 is needed in the brain cells formation to increase level of intelligence. Omega 3 can be acquired from the fishery products. However, the level of fish consumption in Indonesia is still low when compared with FAO recommendations. Long jawed mackerel (Rastrelliger kanagurta $L$.) is a marine fish that contains omega 3 which is good for brain intelligence. The objective of this study was to develop formulations sausage of long jawed mackerel as a food source of omega 3 . This study used experimental method and completely randomized design. The addition of fresh fish that was used as much as $30 \mathrm{~g}$ (FS1), $45 \mathrm{~g}$ (FS2), and $60 \mathrm{~g}$ (FS3), fish flour $6.75 \mathrm{~g}$ (FT1), $13 \mathrm{~g}$ (FT2) and $20 \mathrm{~g}$ (FT3). The best formula from organoleptic test was FS2 which was containing of $44.48 \%$ water, $2.65 \%$ ash, $9.4 \%$ protein, $5.48 \%$ fat, carbohydrates $37.88 \%, 238.48 \mathrm{kcal}$ energy and omega $3 \mathrm{gt} 0,18 \mathrm{~g} / 100 \mathrm{~g}$. The content of omega 3 from long jawed mackerel sausages in $100 \mathrm{~g}$ could be omega 3 source which contribute 20 $\%$ adequacy of omega 3 of children .
\end{abstract}

Keywords: sausage, long jawed mackerel, omega 3, intelligence

\section{Pendahuluan}

Pangan jajanan anak sekolah (PJAS) mempunyai peranan penting karena merupakan sumber asupan gizi penting bagi anak sekolah. Namun, PJAS memiliki masalah mengenai keseimbangan gizinya dan bahan tambahan pangan (BTP) yang melebihi batas. Data BPOM menunjukan pada tahun 2010 pangan jajanan anak sekolah yang tidak memenuhi syarat sebanyak $35,46 \%$. Pengggunan formalin dan boraks pada makanan ringan berturut-turut sebesar $16,06 \%$ dan $9,11 \%$ (Suratmono, 2011).

Lemak dapat mempengaruhi perkembangan kognitif anak. Lemak yang berperan dalam proses tumbuh kembang otak adalah asam lemak omega 3 (Khomsan, 2004). Asam lemak omega 3 adalah asam lemak yang esensial karena dibutuhkan tubuh, sedangkan tubuh tidak dapat mensintesisnya (Almatsier, 2010). Kecukupan asam lemak esensial dalam diet anak usia 7-9 tahun adalah 0,9 g per hari untuk asam lemak omega 3 dan 10,0 g per hari untuk asam lemak omega 6 (Kemenkes, 2013).

Rekomendasikan asupan ikan dari Organisasi Kesehatan Dunia (WHO) setidaknya satu sampai dua porsi per minggu (WHO, 2016). Berdasarkan berbagai laporan FAO, konsumsi ikan per kapita Indonesia merupakan negara yang tertinggal hampir dari semua negara di ASEAN masyarakat, bahkan per kapita konsumsi ikan Malaysia dan Singapura lebih dari dua kali masyarakat Indonesia (KKP, 2013). Berdasarkan data Badan Pusat Statistik (BPS), 
konsumsi ikan segar rata-rata pada tahun 2014 sebesar $14,28 \mathrm{~kg}$ per kapita per tahun.

Ikan kembung (Rastrelliger kanagurta L.) adalah ikan air laut yang banyak didapatkan pada musim puncak (Maret - Juni). Omega 3 dan omega 6 banyak terkandung pada ikan kembung yang baik bagi pencegahan penyakit dan kecerdasan otak. Ikan kembung merupakan salah satu bahan pangan mempunyai kandungan gizi yang memenuhi sejumlah besar unsur kesehatan (Irmawan, 2009). Namun, ikan kembung belum dimanfaatkan secara optimal karena belum ditemukan produk ikan kembung yang praktis dan disukai oleh anak-anak.

Salah satu produk hasil pengolahan daging yang telah dikenal oleh masyarakat adalah sosis. Menurut data survei independen tahun 2010 yang dilakukan oleh sebuah perusahaan swasta, di Indonesia tingkat konsumsi daging olahan seperti sosis dan nugget terus tumbuh dengan baik. Konsumsi sosis oleh masyarakat Indonesia tumbuh rata-rata $4,46 \%$ per tahun (Anggraeni et al., 2014). Sosis merupakan salah satu produk makanan olahan yang banyak disukai oleh masyarakat (Rahardjo, 2003).

Pada penelitian ini, dikembangkan sosis dengan bahan baku ikan kembung sebagai snack cerdas bagi usia anak. Sosis ikan kembung diharapkan memiliki kandungan gizi dan omega 3 yang baik bagi kecerdasan otak anak.

\section{Materi dan Metode \\ Materi}

Bahan baku terdiri dari ikan kembung didapatkan di Pasar Depok Jaya, Depok yang dibuat menjadi ikan lumat dan tepung ikan. Peralatan untuk membuat tepung ikan antara lain steamer, loyang, blender, dan ayakan mesh 80 serta pembuatan sosis antara lain pisau, panci, baskom, sendok, timbangan digital, blender dan stuffer untuk memasukkan adonan dalam selongsong.
Metode

Penelitian meliputi proses pembuatan ikan kembung lumat, tepung ikan kembung dan formulasi sosis ikan kembung, uji organoleptik dan analisa kandungan gizi. Analisa kandungan gizi meliputi analisa kadar air, abu (SNI 01-2891-1992), protein, lemak (AOAC, 2005), karbohidrat (Winarno, 1997), dan omega 3 (BBPP, 2013).

\section{Proses Pembuatan Ikan Lumat}

Ikan kembung lumat didapatkan dengan cara daging ikan hasil fillet digiling menggunakan blender untuk mendapatkan daging ikan lumat. Selama penggilingan, suhu ikan dijaga agar tetap dingin, dengan cara baskom tempat menampung hasil gilingan, diisi dengan es batu dalam kantong plastik untuk menjaga kualitas daging lumat. Suhu penggilingan dijaga pada suhu rendah bertujuan untuk mencegah denaturasi protein aktomiosin.

\section{Proses Pembuatan Tepung Ikan}

Tepung ikan kembung didapatkan dengan mengukus dan mencincang dengan pisau daging ikan hasil fillet. Ikan yang sudah dikukus kemudian dijemur di bawah sinar matahari sampai kering. Ikan kering kemudian digiling lalu diayak hingga halus (80 mesh).

\section{Formulasi Sosis Ikan Kembung}

Formulasi sosis ikan kembung didasarkan pada kecukupan omega 3 anak usia 7-9 tahun, adapun angka kecukupan tersebut adalah 0,9 g. Makanan selingan berupa sosis dengan bahan baku ikan kembung diharapkan dapat memenuhi kecukupan omega 3 anak. Formula sosis pada penelitian ini (Tabel 1) didasarkan pada perbedaan konsentrasi ikan lumat (30\%, $45 \%$, dan $60 \%)$ dan tepung ikan $(6,75 \%, 13,5 \%$, dan 20\%). Penambahan ikan lumat sebanyak $30 \mathrm{~g}$ berpotensi menyumbangkan 15\% kecukupan omega 3 anak 7-9 tahun, sedangkan tepung ikan sebanyak 6,75 $\mathrm{g}$ berpotensi menyumbangkan $16,2 \%$.

Tabel 1. Formulasi Sosis Ikan Kembung

\begin{tabular}{|c|c|c|c|c|c|c|}
\hline \multirow[t]{2}{*}{ Bahan (g) } & \multicolumn{6}{|c|}{ Jumlah } \\
\hline & FS1 & FS2 & FS3 & FT1 & FT2 & FT3 \\
\hline Tepung Ikan & & & & 6,75 & 13,5 & 20 \\
\hline Ikan Segar & 30 & 45 & 60 & & & \\
\hline Tapioka & 34,91 & 19,86 & 4,82 & 33,23 & 26,46 & 19,94 \\
\hline Es & 15 & 15 & 15 & 40 & 40 & 40 \\
\hline STTP & 0,09 & 0,135 & 0,18 & 0,02 & 0,04 & 0,06 \\
\hline Minyak & 7,5 & 7,5 & 7,5 & 7,5 & 7,5 & 7,5 \\
\hline Garam & 1 & 1 & 1 & 1 & 1 & 1 \\
\hline Susu Skim & 2 & 2 & 2 & 2 & 2 & 2 \\
\hline Karagenan & 2 & 2 & 2 & 2 & 2 & 2 \\
\hline Merica & 0,4 & 0,4 & 0,4 & 0,4 & 0,4 & 0,4 \\
\hline Jahe & 0,5 & 0,5 & 0,5 & 0,5 & 0,5 & 0,5 \\
\hline Bawang Putih & 3,5 & 3,5 & 3,5 & 3,5 & 3,5 & 3,5 \\
\hline Bawang Merah & 2,2 & 2,2 & 2,2 & 2,2 & 2,2 & 2,2 \\
\hline Pala & 0,4 & 0,4 & 0,4 & 0,4 & 0,4 & 0,4 \\
\hline Penyedap Rasa & 0,5 & 0,5 & 0,5 & 0,5 & 0,5 & 0,5 \\
\hline Total & 100 & 100 & 100 & 100 & 100 & 100 \\
\hline
\end{tabular}

Keterangan : FS1 $=30 \%$, FS2= 45\%, FS3 = 60\% ikan segar lumat. FT1= 6,75\%, FT2=13,5\%, FT3 = 20\% tepung ikan dari berat total adonan. 


\section{Analisis Statistik}

Data-data hasil uji organoleptik yang didapatkan berupa nilai 6 formula, yaitu formula ikan kembung lumat segar serta formula tepung ikan kembung. Parameter yang dinilai meliputi atribut warna, rasa, aroma, dan tekstur. Panelis sebanyak 50 orang memberikan penilaian berupa garis pada skala tertentu sesuai dengan persepsi masing-masing panelis. Data tersebut dianalisis dengan one way ANOVA, data ang menunjukkan hasil yang berbeda nyata $(a<0,05)$ dilanjutkan dengan uji Duncan.

Setelah didapatkan formula terpilih dilakukan pengujian kandungan gizi. Pada uji kandungan gizi data dibandingkan dengan sosis komersial, melalui uji t.

\section{Hasil dan Pembahasan}

\section{Kandungan Omega 3 Ikan Kembung}

Dalam penelitian ini dilakukan analisis omega 3 untuk mengetahui seberapa besar kadar omega 3 dalam ikan kembung segar dan tepung ikan kembung. Hasil analisis didapatkan bahwa kadar omega 3 ikan kembung segar sebesar $0,45 \mathrm{~g}$ dan tepung ikan kembung sebesar 2,17 g per $100 \mathrm{~g}$. Kandungan omega 3 yang terdiri dari linoleat, EPA, dan DHA pada masingmasing bagian tubuh ikan berbeda-beda. Pada penelitian ini bagian yang dipakai adalah bagian daging ikan.

Kadar omega 3 daging ikan kembung tidak jauh berbeda dengan hasil penelitian Salamah et al. (2004) yaitu berada di antara 0,107-0,507 g per $100 \mathrm{~g}$. Perbedaan kadar omega 3 disebabkan oleh penyimpanan yang dapat berpengaruh nyata terhadap kandungan omega 3 pada bagian daging ikan. Kandungan linoleat pada daging ikan relatif tetap sampai hari ke-8. Kandungan EPA dan DHA pada daging ikan cenderung menurun sampai hari ke-4 penyimpanan sedangkan hari ke-4 sampai ke-8 relatif tetap.

\section{Sosis Ikan Kembung}

Tahapan dalam proses pembuatan sosis ikan kembung meliputi pengadonan, pengisian dalam selongsong, perebusan dan pendinginan. Mula-mula ikan lumat (FS1, FS2, FS3) atau tepung ikan (FT1, FT2, dan FT3) dan tepung tapioka dicampur terlebih dahulu hingga merata, selanjutnya garam, susu skim, karagenan dan STTP. Kemudian ditambahkan es dan bumbu-bumbu yang telah ditumis dengan minyak nabati. Lama pengadonan membutuhkan waktu sekitar 15-25 menit. Adonan yang sudah homogen dimasukkan ke dalam selongsong atau casing yang masih dalam bentuk panjang, untuk itu perlu diikat menjadi bentuk yang kecil dan seragam, berukuran kurang lebih 10-15 $\mathrm{cm}$. Setelah itu adonan direbus pada suhu $80^{\circ} \mathrm{C}$ selama 15-20 menit. Sosis yang sudah selesai direbus, didinginkan dengan cara dimasukan ke dalam air dingin selama 10 menit, kemudian selongsong sosis dilepaskan.

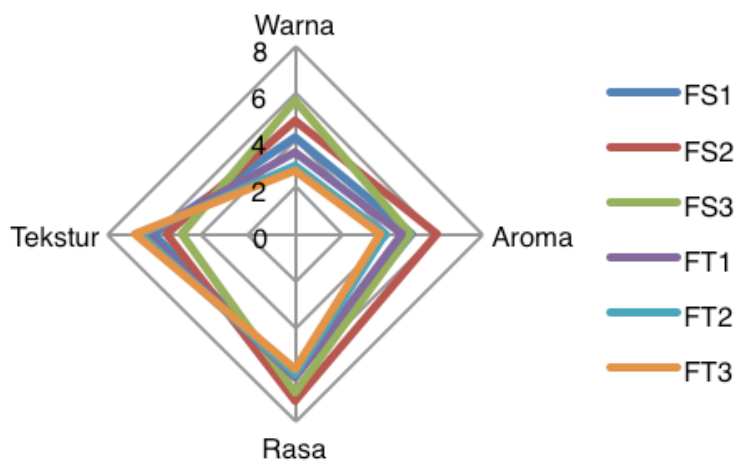

Figur 1. Hasil Mutu Hedonik Sosis Ikan Kembung

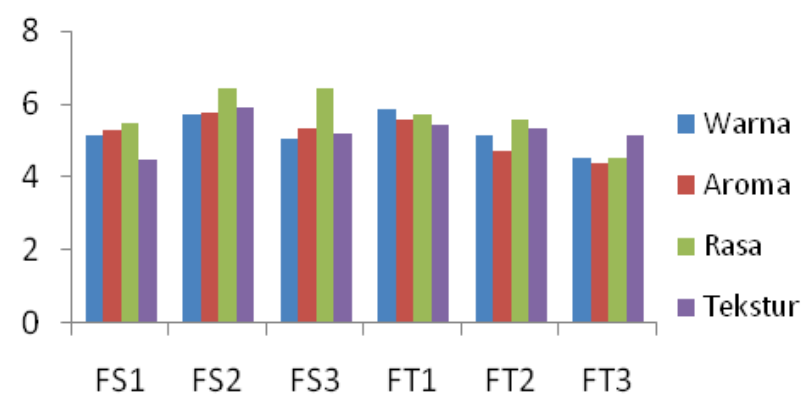

Figur 2. Hasil Hedonik Sosis Ikan Kembung

\section{Karakteristik Organoleptik Sosis Ikan Kembung}

Uji organoleptik sosis ikan kembung dilakukan melalui uji mutu hedonik (Figur 1) dan uji kesukaan (hedonik) (Figur 2). Penilaian organoleptik dilakukan dengan cara melihat, meraba, mencium dan mencicipi sosis ikan kembung. Panelis berjumlah 50 orang yang semuanya berprofesi sebagai mahasiswa jurusan IImu Gizi.

Secara keseluruhan formula yang diterima panelis adalah FS2. Formula terpilih memiliki warna abu-abu tua, aroma agak harum, rasa yang gurih, dan teksturnya netral. Formula terpilih kemudian dianalisis lebih lanjut yaitu analisa uji kandungan gizi sosis ikan kembung.

\section{Kandungan Zat Gizi Sosis Ikan Kembung}

Analisis yang telah dilakukan meliputi energi, kadar air, abu, protein, lemak, karbohidrat, dan omega 3 (Tabel 2). Berdasarkan analisis kandungan gizi, dapat diketahui menurut BSN (2015) pada SNI 01-3820-2015 kadar air, abu, protein, dan lemak sosis ikan kembung maupun sosis ayam komersial sudah memenuhi standar yang ditetapkan. Kadar air sosis ikan kembung lebih rendah dari sosis ayam komersial dan terdapat perbedaan yang signifikan. Semakin rendah kadar air sosis ikan kembung berpotensi memiliki daya tahan lebih lama dibandingkan dengan sosis komersial.

Kadar abu sosis ikan kembung lebih tinggi dari sosis komersial, namun tidak terdapat perbedaan yang signifikan. Tingginya kadar abu pada sosis ikan kembung disebabkan karena kadar abu yang terkandung dalam bahan baku ikan kembung $(1,7 \%)$ relatif lebih tinggi dari ayam $(0,9 \%)$ (PERSAGI, 2009). 
Tabel 2. Kandungan Gizi Sosis Ikan Kembung FS2 dan Sosis Komersial per $100 \mathrm{~g}$

\begin{tabular}{lcccc}
\hline \multicolumn{1}{c}{ Zat Gizi } & Sosis Ikan Kembung & Sosis Ayam Komersial & $(\mathrm{p}$ value $)$ & SNI \\
\hline Air (\%) & 44,48 & 66,22 & 0,001 & $\max .67$ \\
Abu (\%) & 2,64 & 2,51 & 0,321 & $\max .3$ \\
Protein (\%) & 9,40 & 8,08 & 0,008 & $\min .8$ \\
Lemak (\%) & 5,48 & 2,57 & 0,013 & $\max .20$ \\
Karbohidrat (\%) & 37,88 & 20,21 & 0,001 & - \\
Omega 3 (g) & 0,1806 & 0,0355 & 0,003 & - \\
\hline
\end{tabular}

Kadar protein sosis ikan kembung lebih tinggi dari sosis ayam komersial dan terdapat perbedaan yang signifikan. Tingginya kadar protein pada sosis ikan kembung disebabkan karena kadar protein yang terkandung dalam bahan baku ikan kembung $(19,4 \%)$ relatif lebih tinggi dari ayam (18,2\%) (PERSAGI, 2009) dan dimungkinkan penggunaan daging pada sosis komersial yang lebih sedikit.

Kadar lemak sosis ikan kembung lebih tinggi dari sosis ayam komersial dan terdapat perbedaan yang signifikan Tingginya kadar lemak pada sosis ikan kembung dimungkinkan karena perbedaan penambahan lemak nabati antara sosis ikan kembung dengan sosis ayam komersial.

Hasil perhitungan didapatkan kadar karbohidrat sosis ikan kembung lebih tinggi dari sosis komersial dan terdapat perbedaan yang signifikan. Tingginya kadar karbohidrat pada sosis ikan kembung dimungkinkan karena perbedaan penambahan tepung tapioka antara sosis ikan kembung dengan sosis ayam komersial. Rendahnya kadar karbohidrat pada sosis ayam komersial disebabkan oleh tingginya kadar air di dalam sosis tersebut. Sehingga mengurangi persentase karbohidrat di dalamnya.

Kadar omega 3 sosis ikan kembung lebih tinggi dibandingkan sosis ayam komersial dan terdapat perbedaan yang signifikan. Tingginya kadar omega pada sosis ikan kembung dimungkinkan karena kandungan omega 3 dari ikan kembung. Sosis ayam komersial menggunakan bahan baku ayam sehingga kandungan omega 3 pada produk tersebut lebih rendah. Hal ini menunjukkan penggunaan ikan kembung sebanyak $45 \%$ dari total adonan sangat signifikan meningkatkan kadar omega 3 dibandingkan sosis komersial. Jika dibandingankan dengan AKG, kontribusi sosis ikan kembung mencapai 20\% AKG anak usia 7 sampai 9 tahun, sedangkan sosis ayam komersial hanya memberi kontribusi sebesar 3,33\% AKG.

\section{Kesimpulan}

Bahan baku pembuatan sosis ikan kembung ini terdiri dari ikan kembung lumat dan tepung ikan. Formulasi yang diujikan dalam uji organoleptik sebanyak 6 formulasi. Berdasarkan uji organoleptik, formulasi terpilih yaitu FS2 (45\% ikan kembung lumat) yang memiliki warna abu-abu tua, aroma agak harum, rasa yang gurih, dan teksturnya netral. Berdasarkan uji kandungan gizi, formulasi terpilih dalam $100 \mathrm{~g}$ mengandung kadar air $44,48 \%$, abu $2,64 \%$, lemak $5,4 \%$, protein $9,4 \%$, karbohidrat $37,88 \%$ dan omega 3 $0,18 \mathrm{~g}$. Sosis ikan kembung mampu menyumbangkan omega 3 mencapai 20\% AKG anak usia 7 sampai 9 tahun.

\section{Saran}

Penelitian ini masih memiliki banyak keterbatasan seperti aroma aroma amis dan rasa pahit jika menggunakan bahan baku tepung ikan dalam pembuatan sosis. Warna produk juga kurang menarik, sebaiknya dapat dilakukan dengan penambahan pewarna alami.

\section{Ucapan Terima Kasih}

Terima kasih ditujukan pada PT Indofood Sukses Makmur Tbk. yang telah memberikan dana penelitian dalam program Indofood Riset Nugraha Periode 20152016.

\section{Daftar Pustaka}

Almatsier, S. 2010. Prinsip Dasar Ilmu Gizi. PT. Gramedia Pustaka Utama, Jakarta.

Anggraeni, D.A., Widjanarko, S.B., dan Ningtyas, D.W. 2014. Proporsi Tepung Porang (Amorphophallus Muelleri Blume) : Tepung Maizena Terhadap Karakteristik Sosis Ayam. Jurnal Pangan dan Agroindustri Vol. 2 No 3.

Association of Official Analytical Chemists (AOAC). 2005. Official Methods of Analysis of The Association of Analytical Chemists. AOAC, Inc, Virginia.

Badan Pusat Statistik (BPS). 2014. Konsumsi Rata-Rata per Kapita Seminggu Beberapa Macam Bahan Makanan Penting. BPS, Jakarta.

Badan Standarisasi Nasional (BSN). 2015. SNI 203820-2015 tentang Sosis Daging. BSN, Jakarta.

Badan Standarisasi Nasional (BSN). 1992. SNI 012891-1992 tentang Cara Uji Makanan dan Minuman. BSN, Jakarta.

Besar Penanganan dan Pengembangan Pasca Panen (BBPP). 2013. Prosedur Kerja Kromatografi Gas. BBPP, Bogor.

Irmawan, S. 2009. Status Perikanan Ikan Kembung di Kabupaten Barru. Laporan Penelitian. Fakultas Perikanan dan IImu Kelautan, Universitas Brawijaya Malang.

Kementerian Kesehatan (Kemenkes). 2013. Peraturan Menteri Kesehatan Republik Indonesia Nomor 75 Tahun 2013 Tentang Angka Kecukupan Gizi Yang Dianjurkan Bagi Bangsa Indonesia. Kemenkes, Republik Indonesia.

Khomsan, A. 2004. Peranan Pangan dan Gizi untuk Kualitas Hidup. PT Gramedia Widiasarana Indonesia. Jakarta. 
Kementerian Kelautan dan Perikanan (KKP). 2013. Ikan Penyuplai Protein. Warta Pasar Ikan. KKP, Republik Indonesia.

Persatuan Ahli Gizi Indonesia (PERSAGI). 2009. Tabel Komposisi Pangan Indonesia (TKPI). PT Gramedia, Jakarta.

Salamah, E., Hendarwan, dan Yunizal. 2004. Studi Tentang Asam Lemak Omega-3 Dari BagianBagian Tubuh Ikan Kembung Laki-Laki
(Rastrelliger kanagurta). Buletin Teknologi Hasil Perikanan Vol VIII No. II Tahun 2004.

Suratmono. 2011. Pengawasan Keamanan Pangan Jajanan Anak Sekolah. Dipresentasikan pada Acara "Nutrition Day" Jakarta, 5 Oktober 2011.

World Health Organization (WHO). 2016. Population nutrient intake goals for preventing diet-related chronic diseases. Nutrition Topics. WHO.

Winarno, F.G. 1997. Kimia Pangan dan Gizi. PT Gramedia. Jakarta. 